\title{
SUPPORTING SMALL AND MEDIUM SIZED BUSINESSES IN SPECIFIC SERVICES WITHIN SLOVAKIA Jozef Kubás ${ }^{1}$, Viktor Šoltés ${ }^{2}$, Katarína Repková Štofková ${ }^{3}$
}

\begin{abstract}
Providing private security is considered a specific type of business service, primarily carried out by small- and medium-sized enterprises. This specific type of business complements the state services in the field of internal security. State institutions support the creation of small- and medium-sized enterprises through targeted subsidies. The principal goal of this paper is to describe the business environment within Slovakia, focusing on small and medium enterprises providing services of private security. The secondary aim of the paper is to explain the support available for such business through subsidies from public authorities. The number of enterprises that provide services of private security, along with the number of their employees, is relevant. The outputs of the paper can be used as part of the analysis of the competitive environment by subsidy applicants who plan to operate in this specific area.
\end{abstract}

JEL Classification Numbers: J21, F52; DOI: http://dx.doi.org/10.12955/cbup.v6.1166

Keywords: small- and medium-sized enterprises, business environment, private security services

\section{Introduction}

Supporting the business environment is a vital task of the state. Developing the business environment facilitates the lowering of unemployment, improved wages, and increased purchasing power of the population, and thus it progresses the quality of life for the population. In terms of the number of employees, the most important establishments are small- and medium-sized businesses, which employ the majority of the population. These businesses are also foremost because they introduce the possibility of producing goods and services that large businesses cannot. Specific services provided by small businesses include private security.

\section{Running a Business in the Slovak Republic}

In Slovakia, business activity is regulated by several generally binding legal acts. According to Stalmašeková and Štofková (2016), the Constitution of the Slovak Republic is the basis for other laws dealing with the business environment and employment. This constitution accords all individuals the right to a free choice of profession and training to obtain such, as well as the right to engage in entrepreneurial or other gainful activity.

In terms of legal regulation of business activity, the status of entrepreneurs, the rights and duties arising out of business, as well as certain other rights and duties related to business, are regulated by Act No. 513/1991 Coll. (Commercial Code). According to the Commercial Code, the term 'business' means systematic activities. These are independently conducted in the name of an entrepreneur and at the entrepreneur's responsibility for the purpose of making a profit. According to Majerník et al. (2017), an entrepreneur is considered:

- A party registered in the Companies Register,

- A party conducting business pursuant to a Trading License,

- A party conducting business pursuant to an authorization other than Trading License, or

- An individual engaged in agriculture, who is entered in a register.

The conditions of the pursuit of trade activities and the control of compliance therewith regulate the Act No. 455/1991 Coll. (Trade Licensing Act). Any systematic activity pursued independently, in one's name and on one's account, conducted for the purpose of earning profits and pursued under the terms and conditions, as stipulated by Trade Licensing Act, will be deemed a trade. Any natural person (tradesman) or a legal person meeting the conditions (entrepreneur) may carry on a trade.

Regarding the size classification of businesses, Srenkel (2016) noted that the classing of a business as small- or medium-sized is defining for an enterprise, especially when the business owner applies for some forms of state funding. The criteria referring to size are followed by various institutions (e.g., the Offices of Labor, Social Affairs, and Family) that provide the support programs for medium-, small-

\footnotetext{
${ }^{1}$ Faculty of Security Engineering, University of Žilina, Slovakia, Jozef.Kubas@ fbi.uniza.sk

${ }^{2}$ Faculty of Security Engineering, University of Žilina, Slovakia, Viktor.Soltes@ fbi.uniza.sk

${ }^{3}$ Faculty of Operation and Economy of Transport and Communication, University of Žilina, Slovakia, Katarina.Repkova@fpedas.uniza.sk
} 
and micro-enterprises. The size of the enterprise is most often determined by the number of employees, the annual turnover, and the total of the annual balance sheet. These criteria are based on the classification recommended by the European Commission Recommendation No. 2003/361/EC (Table 1).

\begin{tabular}{|l|l|r|r|}
\hline \multicolumn{2}{|l|}{ Table 1: Size classification of enterprises } \\
\hline $\begin{array}{c}\text { Category of the } \\
\text { enterprise }\end{array}$ & $\begin{array}{c}\text { Number of } \\
\text { employees }\end{array}$ & The annual turnover [€] & $\begin{array}{c}\text { The annual balance sheet } \\
\text { total }[\boldsymbol{\epsilon}]\end{array}$ \\
\hline Micro & $<10$ & $\leq 2$ million & $\leq 2$ million \\
\hline Small & 10 to 50 & 20 to 10 million & 2 to 10 million \\
\hline Medium & 50 to 250 & 10 to 50 million & 10 to 43 million \\
\hline Large & 250 and more & 50 million and more & 43 million and more \\
\hline
\end{tabular}

Source: European Commission Recommendation No. 2003/361/EC

Butek and Štofková (2016) point out, that an enterprise belongs to a particular category where it has an appropriate number of employees (the main criterion) and meets at least one other criterion (the annual turnover or the annual balance sheet total).

Micro-, small-, and medium-sized businesses play an important role in the economy. According to the data of the Slovak Business Agency (2016), in Slovakia, small- and medium-sized businesses make up 99.9\% of the total business operators and provide employment opportunities for almost $75 \%$ of the active labor force. According to Soltés (2016), they are also the source of new innovations and technologies, a competitive environment, and economic growth. Furthermore, they produce and deliver products and services that are not offered by large businesses. Figure 1 shows the number of small- (including micro-), medium-, and large-sized businesses in Slovakia.

Figure 1: The development of a number of small and micro ( $\leq 50$ employees), medium (50-250 employees), and large (250+ employees) enterprises in Slovakia

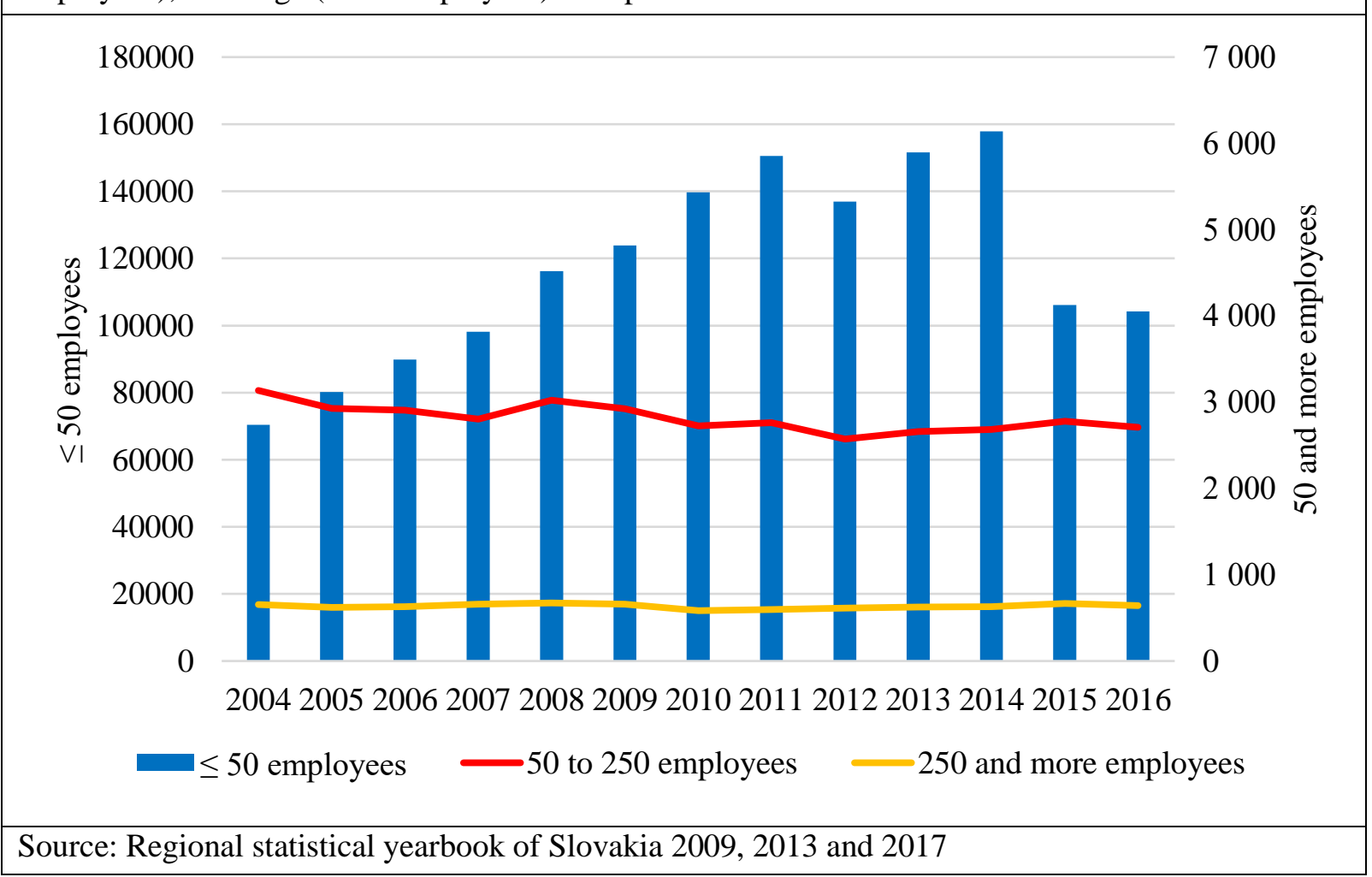

Micro and small businesses have a dominant market position. Over the last ten years, their number has more than doubled. In 2014, their number was close to 160 thousand. In the following year, however, their number fell by almost 50000 and then stabilized. The number of medium- and large-sized businesses has been stable over the long term, with the number of medium-sized businesses oscillating around 2800 and that of large-sized businesses around 650 . 


\section{Business Activities in the Field of Private Security Services}

The provision of services of private security is regulated under Act No. 473/2005 Coll. (Private Security Act). The provision includes private security and technical services. Private security services can be further subdivided into guard service, detective service, and professional training and consultancy. The private security service can be offered to others or for self-protection. For selfprotection, the service is provided on the condition that it involves at least one employed person.

The conditions for granting a license to operate a private security service involve the following. Stofko et al. (2016) notes that operating a security service requires a license that is issued for a period of ten years. After an application is filed, the security service license is granted by an official of the Regional Police Force. According to the Act No. 473/2005 Coll., the Regional Headquarters of the Police Force is the official place for granting of such licenses to a natural person, providing such granting is not precluded because of an internal order or for security reasons. The person needs to be a European Economic Area citizen, over the age of 21 years, with unlimited legal capacity. Furthermore, they need to meet the integrity requirement, be reliable and have the necessary health capacity and professional qualifications.

The number of business operators of private security services in Slovakia was approximately 3500 in 2016. This number had risen by 1000 over the preceding 10 years, based on the record of operators issued with a license to run these services. Figure 2 shows the number of licenses issued by Regional Police Headquarters for the provision of private security services in 2007-2016.

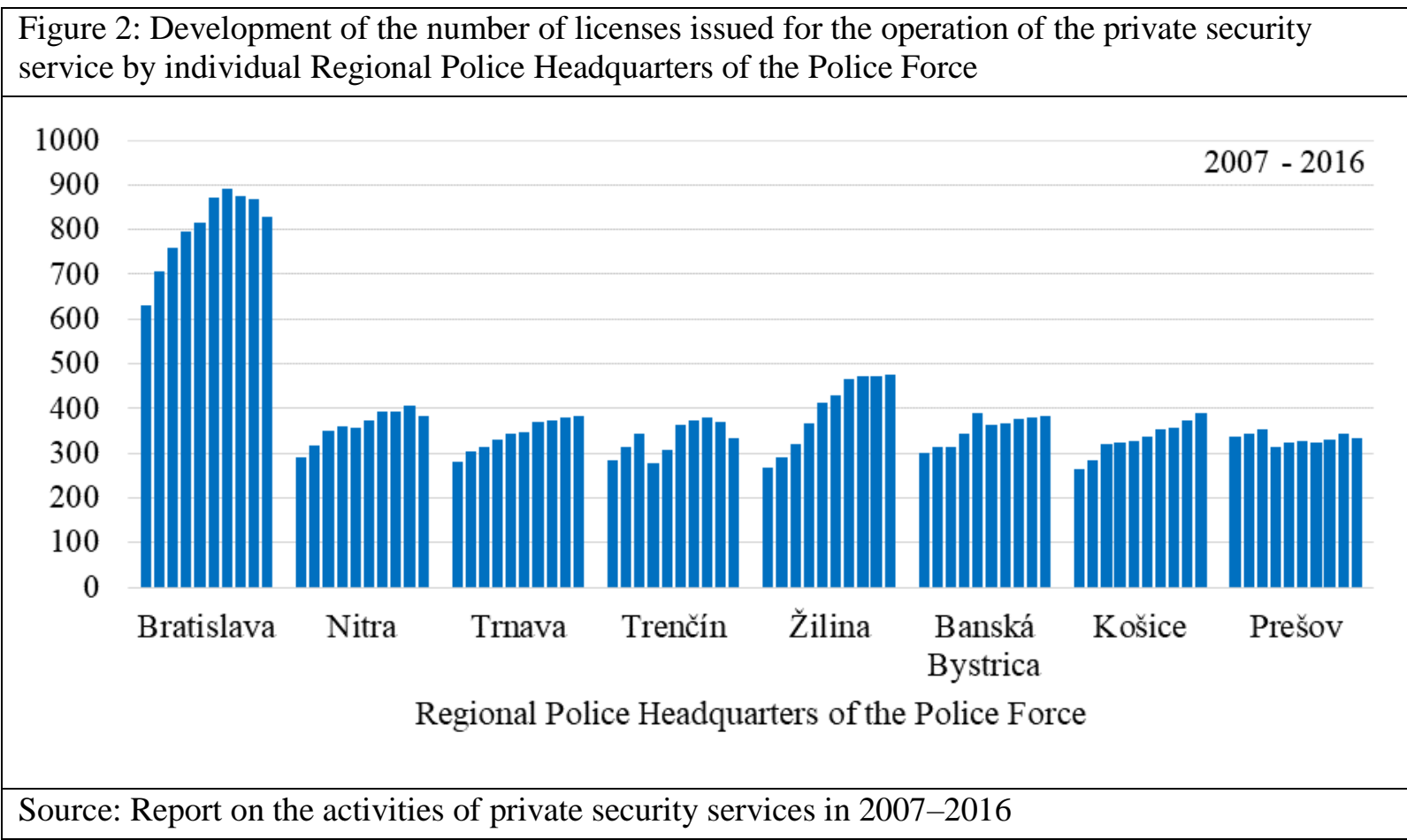

Figure 2 shows that most of the licenses issued for private security services originated in the Bratislava Region during the relevant period. The number of licenses issued in the other regions numbered about half of those issued in Bratislava. Though, in the last two years, the Bratislava Region displays a declining trend in issued licenses. A decrease is also evident in the Nitra and Trenčín Region. Whereas an increasing trend is shown for the Trnava, Banská Bystrica, and Košice Regions, the situation in other Regions appears stable.

A license to operate a security service can be owned by a natural or otherwise, a legal person. Figure 3 shows the number of licenses issued to both natural and legal persons.

The number of licenses issued to legal persons to operate private security services far exceeded those issued to natural persons during 2007-2016. Those issued to natural persons averaged approximately 1000 annually over the ten-year period with a slight downward trend evident over the last three observed years (Figure 3). In contrast, those issued to legal persons increased annually over the ten- 
year period, with the number growing by almost 800 and, by 2016, it exceeded 2500 for the first time (Figure 3).

According to the type, private security services involve five groups: guard service, detective service, and professional training and consultancy, self-protection, and technical service. Figure 4 shows the number for each group of private security services in Slovakia.

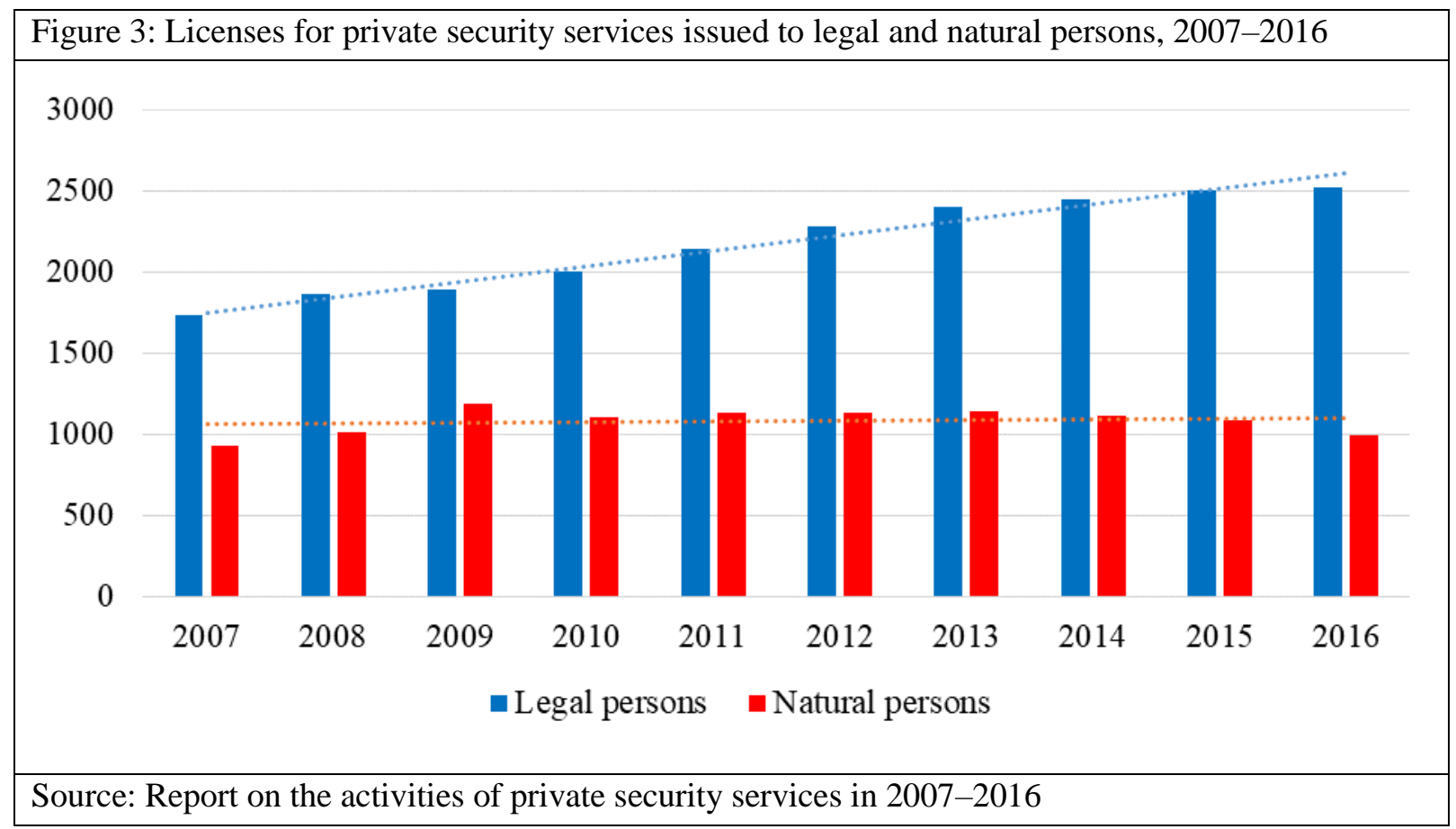

\begin{tabular}{|c|c|c|c|}
\hline Figure 4: Structure of private security services involving five groups, $2007-2016$ \\
\hline 4000 \\
3500 \\
3000 \\
2500 \\
2000 \\
1500 \\
1000 \\
500 \\
0
\end{tabular}

The most frequently provided service was technical. The number of providers of the technical service exceeded that for other types of private security services (Figure 4). Following technical service, the most widespread type of private security service was guard service, then self-protection (own protection). The numbers providing the detective services and professional training and consultancy were the lowest. Since the total for private security services was substantial (3500), the number of staff employed in these services are relevant. Figure 5 shows the number of staff employed in this area over the ten-year period, 2007-2016. 


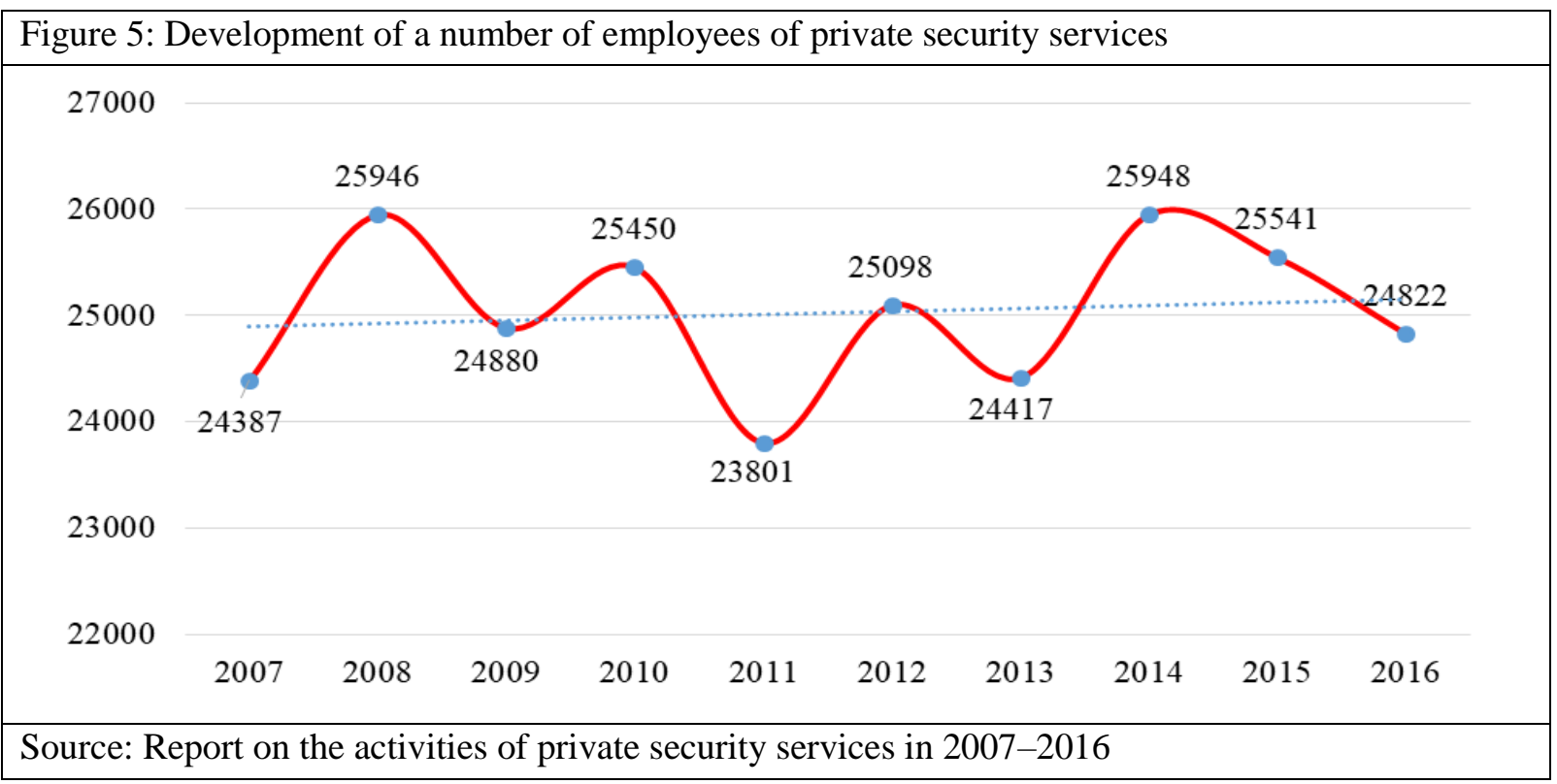

Over this period, the number of private security staff fluctuated (Figure 5). Private security services employed, on the average, 25000 employees with a slight upward trend overall, despite declines in the last two years (Figure 5).

\section{Support for the Business Environment in Slovakia}

The entrepreneurial allowance (subsidies) is regulated by Act No. 5/2004 Coll. (Employment Services Act). The entrepreneurial allowance is provided to successful applicants by the Offices of Labor, Social Affairs, and Family. As at 2018, an entrepreneurial allowance (subsidy) is granted to an applicant who meets the following terms:

- Is considered to be a job seeker,

- Has been a registered jobseeker for at least three months,

- Intends to operate a business for at least three years, and

- Has requested subsidy in writing from the local Offices of Labor, Social Affairs, and Family in whose territorial jurisdiction the business will be conducted.

The entrepreneurial allowance only applies to natural persons. It is not applicable to a legal person. The amount of the entrepreneurial allowance (subsidy) for running a business depends on the unemployment rate in the district where the applicant intends carrying out their activity. According to Seneši (2018), in the Bratislava Region, the maximum amount of entrepreneurial allowance is EUR 3126.47; in the district of another Region where the average registered unemployment rate is less than or equal to $7.21 \%$, the maximum is EUR 3751.77; while in other districts of another Region the maximum is EUR 5002.36.

The first step in obtaining the entrepreneurial allowance involves submitting an application on the prescribed form. Several documents are to be attached; one being a business plan, prepared according to a prescribed outline, with a calculation of the estimated costs. The applicant then needs to pass a test of 'readiness to start a business', after which they are invited to a meeting with the Commission of the Offices of Labor, Social Affairs, and Family, to defend the viability of their business plan. In approving the allowance, the Commission issues a positive recommendation and the applicant signs an agreement with the Offices of Labor, Social Affairs, and Family.

\section{Conclusion}

A thriving business environment is pivotal to the development of society. The state has a responsibility to create a favorable business environment for both legal and natural persons. Small- and mediumsized businesses belong to the most significant part of the business environment. These businesses employ the largest number of employees and through their generation of competitiveness, innovation, and development, they allow their employee numbers to grow. Private security services can also be included in small- and medium-sized businesses. Depending on the business activity, these specific services are classed as guard services, detective services, professional training and consultancy, self- 
protection, and technical service. Most private security services operate in the Bratislava region, with the remaining regions displaying a somewhat equal balance of such services. Operators of these specific services may be legal or natural persons. While the number of natural persons operating such a business remains stable, the number of legal persons operating such is increasing. Overall, in Slovakia in 2016, there were more than 3500 operators of these specific services. The prevailing service is the technical service by a large margin, followed by guard services and self-protection. On average, between 2007 and 2016, approximately 25000 staff were employed in this field. The state creates conditions to support businesses and this support is mainly in the form of financial contributions. In Slovakia, an entrepreneur who intends operating a business can obtain an entrepreneurial allowance (subsidy) when certain conditions are met. This subsidy is granted by the Offices of Labor, Social Affairs, and Family. The maximum amount depends on the region in which the entrepreneur intends operating the business. In the region displaying the highest unemployment rate, the total subsidy can reach EUR 5002.

\section{Acknowledgements}

This paper was undertaken as part of the research project VEGA 1/0696/16, and VEGA 1/0755/18.

\section{References}

Act no. 5/2004 Coll. on Employment Services (Employment Services Act). Retrieved from http://www.ilo.org/dyn/natlex/docs/ELECTRONIC/67700/67637/F1637812241/SVK67700\%20Eng.pdf

Act no. 455/1991 Coll. on Trade Licensing (Trade Licensing Act). Retrieved from https://www.minv.sk/?tradelicencing\&subor $=39253$

Act no. 473/2005 Coll. on the provision of private security services (Private Security Act). Retrieved from http://www.privatesecurityregulation.net/files/2005\%20Law\%20on\%20Private\%20Security\%20Services.pdf

Act no. 513/1991 Coll. (Commercial Code). Retrieved from

https://is.muni.cz/el/1422/jaro2013/SOC038/um/Obchodny_zakonnik_513_1991_v_anglickom_jazyku.pdf

Butek, M., Stofkova, Z. (2016) Relocalisation Trends in the Context of Globalization. ISSGBM International Conference on Information and Business Management, Hong Kong, Singapore: Acad Conf Inst, 61, 33-38.

Constitution of the Slovak Republic. Retrieved from https://www.prezident.sk/upload-files/46422.pdf

European Commission Recommendation No. 2003/361/EC concerning the definition of micro, small and medium-sized enterprises. Retrieved from http://eur-lex.europa.eu/LexUriServ/LexUriServ.do?uri=OJ:L:2003:124:0036:0041:en:PDF

Majerník, M., Daneshjo, N, Sančiová, G. \& Štofková, Z. (2017). Educational and communication support for globalized development strategies by profiling graduates in the field of economics and business management. Globalization and its socio-economic consequences, 17, 1460-1467.

Správa o činnosti súkromných bezpečnostných služieb v roku 2007 - 2016 [Report on the activities of private security services in 2007 - 2016]. Retrieved from https://www.minv.sk/?urad-sukromnych-bezpecnostnych-sluzieb-p-pz

Seneši, N. (2018). Príspevok (dotácia) na podnikanie pre SZČO v roku 2018 [Entrepreneurship grant (subsidy) for SZČO in 2018]. Retrieved from https://www.podnikajte.sk/financie/c/3525/category/financie-na-podnikanie/article/prispevok-dotaciapodnikanie-szco-2018.xhtml

Slovak Business Agency. (2016). Malé a stredné podnikanie v číslach v roku 2015 [small and medium-sized enterprises in figures in 2015]. Retrieved from http://www.sbagency.sk/sites/default/files/msp_v_cislach_v_roku_2015_0.pdf

Šoltés, V. \& Štofková Repková, K. (2016). The impact of business environment on regional disparities. Innovations in science and education, Prague: Central Bohemia University, 4, 187-191.

Štofko, S., Šoltés, V. \& Štofková, Z. (2016). Options of using the integrated management system. Production Management and Engineering Sciences, Leiden: CRC Press/Balkema, 267-272.

Šrenkel, L'. (2016). Malý, stredný alebo mikro podnik - vel'kostné kritériá [Small, Medium or Micro Enterprise - Size Criteria]. Retrieved from https://www.podnikajte.sk/start-podnikania/c/2577/category/podpora-podnikania/article/malystredny-mikro-podnik.xhtml

Stalmašeková, N., Štofková, J. (2016). The entry of a foreign company ('the new brand') into the market in the Slovak Republic. Marketing identity: brands we love, Trnava: Faculty of Mass media Communication, 276-283. 